ELORE (ISSN 1456-3010), vol. $12-2 / 2005$.

Julkaisija: Suomen Kansantietouden Tutkijain Seura ry. Taitto: Jukka Talve ja Outi Fingerroos.

[http://cc.joensuu.fi/ /oristi/2_05/lat2_05.pdf]

\title{
Ajankohtaista: \\ MENNEISYYDEN TULKINTA SUVUN MUISTITIEDON NÄKÖKULMASTA
}

Lectio praecursoria Helsingin yliopistossa 10.6.2005.

Pauliina Latvala

Toukokuun 9. päivänä Euroopassa vietettiin toisen maailmansodan päättymisen 60-vuotisjuhlia. Moskovan voitonpäivän paraatiin osallistui valtionpäämiehiä noin viidestäkymmenestä maasta. Mediassa keskeiseksi aiheeksi nousivat historiallisten tapahtumien tulkinnat ja niihin liittyvät ristiriitaiset tunteet. Menneisyyden rasitteet näkyivät erityisesti Baltian maiden kohdalla, ja saimme lukea sanomalehtien pääkirjoituksista Venäjän omasta historiankäsityksestä ja anteeksipyynnön vaikeudesta. Uutiset korostivat myös sitä, että Venäjän koulujen oppikirjoissa historiaa esitetään kansallistunteella, sankarillisen voittaja-Venäjän näkökulmasta. Virallisen Venäjän sanottiin potevan muistinmenetystä. Toukokuun juhla on osoitus siitä, ettei lähihistorian tulkinta ole ongelmatonta. (Ks. Jakobson 2005; Parkkonen 2005a; 2005b; Raivio 2005.)

Sen, minkä julkinen historiankirjoitus mahdollisesti unohtaa, perheen ja suvun kesken välittyvä suullinen kertomusperinne muistaa. Tästä selkeänä esimerkkinä voisi mainita Viron, jossa sukupolvelta toiselle siirtyvät kertomukset välittivät virolaisten omaa historiaa neuvostomiehityksenkin aikana. Siis aikana, jolloin oli määritelty hyvin tarkasti, kuinka ja mitä historiasta saa puhua julkisesti. Kuinka oli sitten Suomessa? Sodan kokeneet halusivat katsoa eteenpäin ja vaikeista asioista vaiettiin. Vaikuttaa siltä, että yksityinen muistitieto, historiankirjat ja muut historian esitykset ovat jatkuvassa vuorovaikutuksessa keskenään. Tarinaperinne on läsnä historian oppikirjoissa yllättävän vahvasti. Kotimainen kaunokirjallisuus on eri vuosikymmeninä käsitellyt suuria historiallisia tapahtumia nälkävuosista sotiin. Näiden lisäksi muistitiedon ohella esimerkiksi viihteelliset elokuvat vaikuttavat etenkin nuorten historiankäsityksiin.

Historiasta vaikenemisen raja-aidat ovat murtuneet maassamme ennen kaikkea 1960- ja 1990-luvuilla. 1960-luvulla kansalaissodasta järjestettiin useita muistitiedon keruuhankkeita, ja kuten folkloristi Ulla-Maija Peltonen $(1996,2003)$ on tutkimuksissaan osoittanut, muistojen patojen repeydyttyä valkoisten, voittajien, virallisen historian näkökulman rinnalle syntyi hävinneiden, punaisten, historia. 


\section{Pauliina Latvala}

Kolmekymmentä vuotta myöhemmin Neuvostoliiton hajoamisen myötä myös 1930ja 1940-lukujen kokemuksiin oli lupa palata julkisesti. Kun arkistot avautuivat itänaapurissa, monien suomalaisten mieltä painaneet kysymykset omaisten kohtalosta sotavuosina saivat vastauksensa. Sotaveteraanit ja eri tehtävissä työskennelleet lotat, sotaa pakoon lähetetyt lapset sekä sodan Suomessa kotioloissa kokeneet halusivat vanhetessaan puhua eletystä elämästä. Lähes viidentoista vuoden aikana on syntynyt valtavasti historian henkilökohtaisesta kokemuksesta kertovia tekstejä, joista osa on julkaistuja, osa omakustanneteoksia, osa painamattomia muistelmia.

Naisten ja miesten elämäkertoja on tallennettu Suomalaisen Kirjallisuuden Seuran kansanrunousarkistoon useaan otteeseen. Elämäkertojen tutkimus on muodostunut poikkitieteelliseksi ja historiantutkimuksessa on lisääntynyt henkilöja elämänhistoriallinen tutkimusote. Tämä on kasvattanut eri alojen tutkijoiden kiinnostusta tavallisten ihmisten kokemuksia kohtaan. Perinteentutkijat ovat perehtyneet muun muassa kerronnan rakentumiseen ja kulttuuristen mallien esiintymiseen ja tulkintaan.

Elämäkertojen rinnalla muistitiedon sekä niin kutsutun kansanomaisen historian ja ajattelun tutkimus on noussut oppiaineessamme suosituksi. Tutkimuskohteena on ollut sekä yleinen että johonkin teemaan tai aikakauteen kohdistuva muistitieto. Lisäksi on tutkittu paikallisuutta. Alueellisuuden huomioon ottaminen ja paikallishistorian tuntemuksen hyödyntäminen tuovat kiinnostavia tutkimuskohteita ja -tuloksia.

Muistitiedon ja kerronnan tutkimuksen kehyksissä olen viime vuosina pohtinut sitä, kuinka suomalaisten historiatietoisuus muodostuu ja mitä historiakerrontaan kuuluu. Ajatusta voidaan laajentaa edelleen ja kysyä: Missä menneisyys on, missä menneiden sukupolvien elämä kokemuksineen on ja kuinka ihmiset kokevat paikkansa sukupolvien ketjussa? Väitöstutkimukseni avainkysymykseksi muodostui se, miten vuoropuhelu menneisyyden kanssa toteutuu, kun historiasta kerrotaan suvun ja perheen näkökulmasta.

Tutkimusaineistonani ovat tekstit, joita kerättiin itsenäisen Suomen täyttäessä 80 vuotta vuonna 1997. Suvun suuri kertomus -niminen keruukilpailu oli yksi juhlavuoden kymmenestä ydinhankkeesta. Sen toteutti Suomalaisen Kirjallisuuden Seura yhteistyökumppaneinaan Suomi 80 vuotta -toimikunnan lisäksi Kalevalaisten Naisten Liitto ja Suomen kotiseutuliitto. Keruu tavoitti yli 700 suomalaista ja tuotti monipuolisen tutkimusaineiston niin sisällöllisesti kuin rakenteellisestikin (ks. Latvala 2001).

Vastaajakunnan enemmistö on korkeasti koulutettuja kaupunkilaisia, vaikka perinteisesti vastaajissa runsaasti edustettuina ovat olleet sukutilalla eläneet maanviljelijät ja emännät. Tämän selittänee se, että suvun juurista haluavat kirjoittaa ne henkilöt, jotka ovat eläneet suuren murroksen ja modernisaation aikaa. Ne, joiden juuret ovat maalla, jotka ovat tulleet kaupunkeihin opiskelun tai työn perässä tai jotka ovat joutuneet jättämään kotiseutunsa Karjalassa sodan vuoksi. 1990-luvun lopussa ihmiset tunsivat tarvetta kertoa paitsi tapahtumista, myös niiden tulkinnoista ja niihin liittyvistä ajatuksista ja tunteista. 


\section{LeCtio: MeNneisyyden TULKinTA}

Naishistorian tutkijat ovat tähdentäneet, etteivät naiset ja miehet jaa samaa historiaa eivätkä kysy historialta samoja kysymyksiä. Molempien sukupuolien tarvitaan, jotta historia kertoisi ihmiskunnan muistista. Naiset ovatkin tietoisesti pyrkineet kirjoittamaan historiaa uudelleen ja oikaisemaan vääristynyttä, naisten historiaa sivuuttavaa, miespainotteista historiaa. Historian lisäksi naiset ovat jääneet miesten varjoon sukututkimuksessa; heitä ei ole vanhoissa rekistereissä merkitty ylös yhtä tarkasti kuin miehiä, ja yleensä naiset on mainittu vaimoina miestensä yhteydessä. Hämmästyttävän yleiseltä vaikuttaa käsitys, että suku jatkuu vain mieslinjaa pitkin. Naisethan konkreettisesti saattavat seuraavan sukupolven maailmaan ja voivat pitää sukunimensä avioiduttuaan.

Tutkimusaineistostani ilmenee, että suvun muistitieto on tärkeä väylä historian ja naisten kokemusten esittämiselle. Monesti kertomukset jäsentyivätkin esimerkiksi sadan vuoden ajalle kolmeen sukupolveen: isoäidin, äidin ja tyttären elämään. Näyttää siltä, että muistelukulttuuri on jossain määrin sukupuolisidonnaista. Naiset ja miehet painottavat eri piirteitä perheen ja suvun historiasta. Miesten teksteissä tyypillistä on suvun maantieteellisen alkuperän etsintä, heimoerojen selvittäminen, maatilojen omistussuhteiden ja perintöosuuksien vaiheet sekä suvun kantahenkilön esitteleminen. Suvun kertomuksia kirjoittavat miehet eivät mainitse kantahenkilöksi naista, vaan miessankari pyritään löytämään mahdollisimman kaukaa historiasta. Sankariksi hyväksytään mies, jolla oli yhteisössä vaikuttajan rooli tai muuten myönteisiä mielikuvia herättävä tausta. Historiallisista tapahtumista miehet kirjoittavat naisia useammin dokumentoivaan tyyliin, etäistäen henkilökohtaiset kokemukset.

Naisten kerronnassa keskitytään suvun sisäisten ihmissuhteiden kuvauksiin sekä arkiseen perhe-elämään, jolloin kantahenkilöä tärkeämmäksi nousevat arjen sankarit, jotka jaksoivat elää vaikeuksien keskellä. Vanhempien naisten teksteissä korostuvat koulutukseen liittyvät toiveet ja niihin lähiyhteisössä kohdistunut torjunta. Historialliset tapahtumat naiset kytkevät konkretiaan. He kirjoittavat esimerkiksi siitä, miltä mahtoi tuntua, kun Amerikkaan siirtolaiseksi lähtenyt puoliso ei lupauksesta huolimatta tullutkaan takaisin, tai kuinka kotipellolla työskentelevät venäläiset vangit olivat lapsille ystävällisiä. Naiset sijoitetaan sekä naisten että miesten teksteissä historian toimijoina sankareiksi. Näin etenkin silloin, kun ei kerrota omasta elämästä. Isoäiti ja äiti näyttäytyvät varsinkin kansalaissodan aikana rohkeina ja nokkelina. He pelastivat omaisiaan varmalta vankeudelta ja nälkäkuolemalta, piilottelivat metsäkaartilaisia ja niin edelleen. Huumorilla höystetyt kertomukset siitä, kuinka aseeton nainen ja aseistettu mies kohtaavat, ovat melko tavallisia.

Seuraavassa aineistoesimerkissä silmiinpistävää on kunnioituksen hankkiminen taitavalla sanankäytöllä:

Isäni äiti kertoi ensimmä̈sen maailmansodan ja "kapinan" ajasta Vïpurissa. Mm. miten venäläinen upseeri tuli hänen ruokalaansa ja vaati isolle seurueelle ruokaa ilman ostolupia ja kun isoäiti oli sanonut, ettei ilman kuponkeja voinut antaa leipää eikä muntakaan ruokaa, oli upseeri vetänyt sapelinsa tupesta ja ubannut isoäitiäni. Isoäitini oli byvin pelkäämätön nainen. Hän oli vain katso- 


\section{Paulitina Latvala}

nut tiukasti venäläistä upseeria ja sanonut, että Herra kapteeni, minun päästäni lähtee byvin vähän leipää. [..] tuo oli tehonnut upseeriin. Hän oli tehnyt kunniaa, kääntynyt kantapäillään ja marssinut ulos. (SKS. SUKU 9069-9070. 1997, nainen s. 1934.)

Sotavuosiin sijoittuvat sankarinaiskuvat eivät kuitenkaan ole ainoita, vaan naisten katsotaan selviytyneen pakon edessä myös rauhan aikana arjen vaikeuksista, suuresta lapsimäärästä, leskeydestä ja omaisten kuolemantapauksista. Paljon puhuttua suomalaista sisua näyttää löytyvän myös muualta kuin suosta, kuokasta ja Jussista. Kertomukset historian tapahtumista peilaavat yksilön kokemusten lisäksi koko yhteiskuntaa. Suvun menneisyydestä ja omasta elämästä kerrottaessa on tapana esittää yhteisöllisempiä näkökulmia etenkin silloin, kun kerrotaan sotavuosista. Tapahtumista saatetaan kertoa ensin yleisellä tasolla, sitten paikalliseen viitaten ja lopulta yksityiseen pureutuen. Näin esimerkiksi vuonna 1931 syntyneen miehen mukaan:

Sotiin osallistuneet tuomittiin vasemmistoradikaalien toimesta heti sodan jälkeen lähes rikollisiksi, joka osaltaan aiheutti vaikenemista. Esimerkiksi kotikyläni kommunistit vannoivat, että kun he pääsevät valtaan, suojeluskuntalaiset ammutaan välittömästi ja sotilaspojat lähetetään Siperiaan viisastumaan. Itse toimin jatkosodan ajan sotilaspojissa ja isäni oli ollut suojeluskuntalainen, joten kyllä ubkaus bieman hirvitti. (SKS. KRA. SUKU 6830. 1997, mies. s. 1931.)

Edellisessä esimerkissä näkyvät muistoihin liittyvät tunteet: katkeruus, pelko ja viha sävyttävät katkelmaa. Valtaosa suvun muistitiedosta sisältää voimakkaita tunteita, jotka liittyvät historian kiistämiseen, ymmärtämiseen tai selittämiseen. Kertojat ovat toisinaan ajatelleet, kuinka olisivat itse toimineet vastaavassa tilanteessa tai millainen nykyisyys olisi, mikäli menneisyys olisikin mennyt toisin. Emotionaalisuutensa vuoksi kertomukset jäävät kuulijoiden mieleen ja voivat askarruttaa heitä vuosikymmeniä.

Tänä päivänä suomalaisten lasten ja nuorten arkeen eivät kuulu kerjuureissut talosta taloon tai metsässä piileskely sodan vuoksi. Kuullessaan toistuvasti sukulaisten kertomuksia siitä, kuinka perheenjäsenet yrittivät tehdä kaikkensa saadakseen omaisensa hengissä kotiin tai hankkiakseen leipää perheelle, saattaa sukupolvien välinen kuilu tuntua käsittämättömältä.

Kertomusten voimana on vahvistaa niissä esiintyviä näkemyksiä, eli ne voivat toimia myös opetus- tai varoituskertomuksina, mutta toisaalta ne toimivat myös päinvastoin. Osa kuulijoista kritisoi kertomusten välittämiä arvoja. Nuoremmat sukupolvet haluavat myös vapautua edellisten sukupolvien ahdistuksesta, joka välittyy muistitiedossa kertomuksina tai vaikenemisena. Lukiessani sukupolvien elämästä kertovia tekstejä minua jäi askarruttamaan, kuinka laajasti suvun kohtalot ovat vaikuttaneet arvomaailman muodostumiseen. Erityisesti tutkimusaineistosta nousi esiin vihjeitä siitä, että historian kokemisella ja poliittisten käsitysten muodostumisella on melko vahva yhteys toisiinsa. 


\section{LeCTIO: MenNeISYYDEN TULKINTA}

Olen tullut siihen lopputulokseen, että historian tapahtumista kirjoittamisen lisäksi agraarikulttuurin kuvaileminen, maaseudun muutosten peilaaminen ja oman elämän liittäminen suomalaisen elämän muuttumisen jatkumoon on koettu tärkeäksi. Suomalaiset katsovat menneisyyteen monipuolisesti, kukin kertoja luo menneisyyskertomuksen omista lähtökohdistaan painottaakseen itselle tärkeäksi muodostuneita vaiheita ja näkökulmia. Menneisyys on joka puolella, eikä missään enää samanlaisena kuin se oli tapahtumahetkellä. Menneiden sukupolvien elämä on paitsi aineellisissa dokumenteissa ja valokuvissa myös tunteissa ja muistoissa, sanoina, sanavalintoina ja erilaisina painotuksina menneisyyttä hahmottavissa kertomuksissa.

Haluan päättää lektioni tutkimusaineistosta löytyneeseen tekstisitaattiin, josta käy ilmi, kuinka tärkeäksi suvun kertomuksen kirjoittanut vastaaja on kokenut menneisyyttä hahmottavan kirjoitusprosessin. Kirjoittaja on 29-vuotias nainen:

Ennen kirjoitustyön aloittamista esitin itselleni kysymyksen: "Kannattaako tätä kirjoittaa?" Nyt, saatuani työn tehdykesi, vastaan miettimättä: Kyllä!, sillä jo tarinan terapeuttinen vaikutus on korvannut minulle kirjoittamisen vaivan. Nuo ylitsevyörynneet lukuisat tunteet ja tuntemukset selkiyttivät sekä maailmankuvaani että omakuvaani. Ne illat ja yöt, jotka vietin kirjoittaen, saivat minut tuntemaan ylpeyttä itsestäni ja siitä, että olen valinnut oman tieni ja pysynyt sillä, turbia kuvia kumartamatta. Ja vaikeka välillä kirjoitin läpi kyynelten, en kadu niitäkään. Helppoa tämä ei siis ole ollut kirjoittaa, mutta belpottavaa on, että siitä buolimatta tein sen. (SKS. KRA. SUKU 27424. 1997, nainen, s. 1968.)

\section{TutKImusaineistot}

\section{Arkistolähteet:}

Suomalaisen Kirjallisuuden Seuran kansanrunousarkiston Suku-keruu.

\section{Sanomalehdet:}

JAKOBSON, MAX 2005: Toukokuun 9. päivä. - Helsingin Sanomat 7.5.20005. [Kolumni.]

PARKKONEN, MIKA 2005a: "Hyvää päivää, rakkaat toverit!" - Helsingin Sanomat 7.5.2005.

— 2005b: Venäjän kouluissa sotaa ei arvostella. - Helsingin Sanomat 7.5.2005.

RAIVIO, JYRI 2005: Bushin Euroopanmatkalla on kaksi teemaa. - Helsingin Sanomat 6.5.2005.

Venäjän anteeksipyyntö Baltian mailta sietämättömän vaikeaa. - Helsingin Sanomat 8.5.2005. [Pääkirjoitus.] 


\section{Pauliina Latvala}

\section{KiRJALlisuUs}

LATVALA, PAULIINA 2001 (toim.): Suvun suuri kertomus. Muistitietoa itsenäisestä Suomesta. Suomalaisen Kirjallisuuden Seura. Kansanelämän kuvauksia 53. Helsinki: Suomalaisen Kirjallisuuden Seura.

PELTONEN, ULLA-MAIJA 1996: Punakapinan muistot. Tutkimus työväen muistelukerronnan muotoutumisesta vuoden 1918 jälkeen. Suomalaisen Kirjallisuuden Seuran Toimituksia 657. Helsinki: Suomalaisen Kirjallisuuden Seura.

- 2003: Muistin paikat. Vuoden 1918 kansalaissodan muistamisesta ja unohtamisesta. Suomalaisen Kirjallisuuden Seuran Toimituksia 894. Helsinki: Suomalaisen Kirjallisuuden Seura.

Pauliina Latvala. Katse menneisyyteen. Folkloristinen tutkimus suvun muistitiedosta. Suomalaisen Kirjallisuuden Seuran Toimituksia 1024. Helsinki: SKS. 2005.

FT Pauliina Latvala on helsinkiläinen folkloristiikan tutkija. 